\title{
The Effect of the Kinanthropometric Profile on Leg Strength and Hand Grip Strength in Young Female Swimmers
}

\author{
İbrahim Can NEFESOĞLU $\quad$ Orhan BAŞ²
}

\begin{abstract}
Morphological structure and anthropometric values are the most important factors affecting sporting performance and success. Alongside these elements, the relationship between basic motoric characteristics and sporting success should also not be underestimated, and strength is regarded as a precondition for numerous branches of sport. The purpose of the present study was to examine the effect of the kinanthropometric profile on leg strength and hand grip strength in young female swimmers in order to evaluate the relationship between physical structure and strength.

The swimmers whose anthropometric measurements were obtained were all licensed athletes in our region. The athletes in the study were aged 9-14 years, and measurements were performed in the pool in the presence of their coaches before morning training. After athletes' height and weight had been measured, a total of 24 anthropometric measurements were performed on all participants, including circumference, diameter, width, and length values, using an anthropometric set. Athletes' hand grip and leg strength were then measured using hand and foot dynamometry. Data compatibility with normal distribution was assessed using the KolmogorovSmirnov test $(\mathrm{p}>0.05)$.

Levels of relationships between measurement values were determined using Pearson's correlation coefficient. The research findings were expressed as mean plus standard deviation. Analysis revealed positive correlation between all anthropometric measurements and hand grip strength and leg strength.
\end{abstract}

Keywords: Anthropometry, Swimming, Hand Grip Strength, Leg Strength.

\section{Genç Kadın Yüzücülerde Kinantropometrik Profilin Bacak Kuvveti ve El Kavrama Kuvveti Üzerine Etkisi}

\section{ÖZ}

Morfolojik yapı ve antropometrik değerler sportif performansı ve başarıy etkileyen önemli parametrelerdir. Bu öğeler ile birlikte temel motorik özelliklerin sportif başarı ile olan ilişkisi göz ardı edilemeyeceği gibi bir çok branş açısından kuvvet özelliği ön şart olarak kabul edilmektedir. Fiziksel yapı ve kuvvet arasındaki korelasyonu değerlendirmek amacıyla çalışmamızda genç kadın yüzücülerde kinantropometrik profilin bacak kuvveti ve el kavrama kuvveti üzerine etkisini incelemeyi hedefledik.

Antropometrik ölçümlerini aldığımız yüzücüler bölgemizde bulunan lisanslı sporculardır. Çalışmaya katılan sporcular 9-14 yaş aralı̆ı̆ında olup ölçümler antrenman saatinden önce havuzda antrenörlerin nezaretinde gerçekleştirildi. Sporcuların Boy, kilo, ağırlık ölçümleri alındıktan sonra antropometrik set ile çevre, çap, genişlik ve uzunluk ölçümleri olmak üzere her sporcudan toplam yirmi dört antropometrik ölçüm alındı daha

${ }^{1}$ Ordu University, Ordu-Turkey, ibrahimnefesoglu@ @otmail.com, 0000-0002-8525-3677

${ }^{2}$ Sorumlu Yazar: Samsun University, Samsun- orhanbas55@ @otmail.com, 0000-0002-7449-2699 
sonra el ve ayak dinamometresi kullanılarak sporcuların el kavrama ve bacak kuvveti ölçüldü. Veriler öncelikle Kolmogrov-Smirnow testi ile normallik varsayımı kontrol edildi $(\mathrm{P}>0.05)$.

Ölçüm değerleri arası ilişki düzeyleri Pearson korelasyon katsayısı ile belirlendi. Araştırma bulguların, ortalama, standart sapma olarak verildi. Analizlerin sonucunda tüm antropometrik verilerin el kavrama kuvveti ve bacak kuvveti ile aralarında pozitif korelasyon tespit edildi.

Anahtar kelimeler: Antropometri, Yüzme, El Kavrama Kuvveti, Bacak Kuvveti.

\section{INTRODUCTION}

All societies invest time, energy, and money to develop projects for identifying abilities in different branches of sport in which they wish to achieve success, for identifying these abilities early and improving them, and for producing successful athletes. However, the investment in these projects can only achieve the desired results through research performed in the light of scientific data (Arabac1, 2008).

The successes and championships achieved in international sporting contests, especially in recent years, have not been won easily. The road to success therefore requires proper planning (Zorba, 1999). The production of talented athletes relies on talent-spotting at an early age, with children being directed toward those branches in which they will be most successful. The aim of talent spotting is to select and identify athletes with abilities in a particular branch of sport (Bompa, 1985). Physical assessment tests before and at the onset of adolescence are as important in swimming as in all other branches. All these characteristics need to be measured and monitored in order to encourage individuals toward swimming at the right time and to produce successful athletes. The establishment of appropriate training systems in this way will also prevent loss of time on the part of coaches (Bostanc1, 2017).

Revealing the abilities of young athletes in the branch to which they feel most attracted is an important factor in establishing branch infrastructures and in success in the chosen field. Talented athletes also need to be produced in order to establish infrastructures in branches of sport and to compete on international platforms (Pate, Freedson and Sallis, 2002).
One of the important factors shown to affect performance is athletes' anthropometric characteristics. Previous studies have shown that these affect physical performance (Pavlicevic, 2005; Le, Labelle, Forest and Poitras, 1998; Zorba and Ziyagil, 1995). Kinanthropometric measurement data allow the athlete's physical measurements to be accurately compared and evaluated (Ergün and Baltac1, 1997). The data resulting from these comparisons are interpreted in percentage terms (Dündar, 2015).

Studies involving anthropometric characteristics from different parts of the world discuss which body profiles are more appropriate for which branches of sport and investigate the importance that this plays in infrastructure selection (Lale, Müniroğlu, Çoruh and Sunay, 2003). Scientific research has confirmed that athletes achieving success in specific sporting fields also exhibit specific body structures (Turnagöl, Demirel and Aritan, 1992).

\section{Purpose}

In the light of the importance of swimming in terms of both performance and health, the present study was performed in order to examine the effect of anthropometric characteristics on hand grip strength and leg strength among licensed swimmers.

\section{METHOD}

\section{Participant Selection}

One hundred licensed young female swimmers aged between 9 and 14 were included in the study. The reason for choosing athletes between the ages of 9-14 in our study is the higher number of athletes in this age range in the Black Sea Region. The study 
began after receiving permission from Ordu University Clinical Research Ethics Committee dated 10.08.2017 and numbered 91. Before beginning the measurements, each sportsperson and trainer were given detailed information about the study and then signed a voluntary consent form.

\section{Measurement}

Athletes were given the necessary theoretical information about the measurements and tests before the procedures began. The athlete's age, weight, height, and length, diameter, and circumferential measurements were recorded. Equipment included an anthropometric set, scales, a tape measure, and hand and leg dynamometers. Anthropometric measurements were taken from the right side, with the athlete standing erect. Hand grip measurements were taken using a dynamometer, repeated for each hand, the best result being used for analysis. Leg strength measurements were taken using a leg strength dynamometer, repeated twice, the best result being included in the analysis. All measurements were performed under the same conditions, with patients in a fasting state. Measurement forms were prepared for all athletes, and the results were recorded onto these.

\section{Anthropometric Measurements}

\section{Height Measurement}

Height was measured in the anatomical position, with the subject barefoot, using a line parallel to the floor touching the head during deep inspiration. The distance was measured between this and the sole of the foot using the anthropometric set, the upper limit being the plane tangential to the vertex.

Sitting height was determined by measuring the distance between the vertex and the sitting surface with the patient seated on a wooden bench (Kızılakşam, 2006).

\section{Weight Measurement}

Weight was measured with the subject barefoot and wearing a swimming costume, in a fasting state, using a digital scale sensitive to $100 \mathrm{~g}$ (Özkan and Sarol, 2008).

\section{Circumference Measurements}

Wrist circumference: The distance was measured with the tape measure in full contact with the styloid processes of the radius and ulna (Yusufreisoğlu, 2009).

Forearm circumference: Measured using the tape measure $10-15 \mathrm{~cm}$ above the styloid process or the point of maximum girth (İkiz, Y1lmaz, Akça and Çankaya, 1995).

Shoulder circumference: Measurements were performed with the arms slightly abducted, with the patient standing erect, and with the tape measure encircling the axillary region and passing over the acromion (Özer, 2009).

Arm circumference: This was measured using a tape measure $10-15 \mathrm{~cm}$ above the epicondylus medialis or the point of the muscle with the greatest girth, with the muscles in a relaxed position (Fry and Morton, 1991).

Head circumference: The widest area was measured with the tape measure being passed immediately above the occipital prominence and muscles in the Frankfort plane (Canl1, 2016).

Thigh circumference: This measurement was performed with the subject in a standing position with her weight on her left leg, the other leg being in a relaxed state, from 10-15 $\mathrm{cm}$ above the patella or at the point of widest girth (Zorba and Ziyagil, 1995).

Hip circumference: This was measured from thepubis in the front to the most protruding part of the gluteal region in the rear (Korkmaz, Arabac1, Çankaya and Şahin, 2008).

Calf circumference: This measurement was taken with the subject standing and her balance equally distributed, based on the point of maximum visible girth and from the widest part of the gastrocnemius muscle (Özer, 2009).

\section{Breadth Measurements}

Biacromial distance: This was measured as the distance between the right and left acromial processes with the subject in the anatomical position (Kılınç, Cesur, Atay, Ersöz and Kılıç, 2010). 
Biiliocrestal breadth: Measured as the longest distance between the right and left iliac crests with the subject in the anatomical position (Tuncer, 2004).

Anteroposterior thorax: Measured as the distance between the manubriosternal joint and the fourth thoracic vertebra (McArdle, 1971).

Transversal thorax: The distance between the most lateral parts at the level of the fourth rib with the arms in abduction (Ç.kmaz, Taşkınalp, Uluçam, Yılmaz and Çakıroğlu, 2005).

Hand breadth: Measured using the anthropometric set as the transverse distance between the most external points of the hand at the level of the first and fourth metacarpophalangeal joints (Atasoy, 2018).

Foot breadth: Measured with the subject standing and in bare feet as the distance between the most external points of the foot at the level of the first and fifth metatarsophalangeal joints (İçten, Süllü, and Tuncer, 1995).

\section{Length Measurements}

Upper extremity length: This was measured with the patient in the anatomical position with the arms alongside the trunk by gentle application of the fixed arm of the anthropometer to the acromial processand with the mobile arm extended to the tip of the middle finger (Baş, Paktaş, Özen, Songur, Üçok, Mollaoğlu and Toktaş, 2006).

Lower extremity length: The length of the lower extremity was measured between the anterior superior spinailiaca and the malleolus medialis (Otman, Demirel and Sade, 2014).

Forearm length: This was measured with the arms hanging freely, the elbows bent at $90^{\circ}$, the forearms parallel to the ground and to each other, the hands straight at the wrist, and with the palms facing the ground, by attaching the fixed arm of the anthropometer to the posterior tip of the olecranon and the mobile arm to the most distal point of the radial styloid process (Akdoğan, Özdemir, Hasusta, Akyer, Akdoğan and Akdağ, 2005).
Foot length: Measured with the subject in a standing position as the distance between the furthest point of the toes and the tip of the heel (Malas, Doğan, Evcil, Desdicioğlu, Tağıl, Sulak and Çetin, 2005).

Hand length: Measured with the forearm and hand in a straight line, without bending the wrist, with the fingers in abduction and extension from the dorsal part of the hand, the fixed end of the anthropometric set being attached to the most distal point of the radial styloid process and the mobile arm to the tip of the longest finger (Kılınç, Cesur, Atay, Ersöz and K1lıç, 2010).

\section{Hand Grip Strength Measurement}

Hand grip strength was measured using a hand dynamometer, with the subject in a standing position, the arm being kept straight without bending at the elbow or touching the body. The dynamometer needle was turned to face the individual performing the measurement, and was carried out with the subject applying grip force. Three measurements were taken for each hand, the best value being recorded (Saygın, Polat and Karacabey, 2005).

\section{Leg Strength Measurement}

Leg strength was measured once the athlete had placed her feet on the base of the dynamometer, with her knees bent, with the arms tensed, the back straight, and the trunk inclined slightly forward. Measurement involved the athlete using her legs to raise the dynamometer bar held in her hands to the maximum vertical position. This was repeated twice, and the best value was recorded for each participant (Alp, Kılınç and Suna, 2015).

\section{Statistical Analysis}

The data obtained from the research were first analyzed for normality using the Kolmogorov-Smirnov test. The most widely employed method in performing regression analysis, on condition that the requisite conditions are met, such as normality, is the least squares method. This is based on reducing the sum of the squares of the differences between the (theoretical) $\mathrm{Y}$ values yielded by the equation and the (true) $\mathrm{X}$ values yielded by the measurements. In 
Nefesoğlu, İ.C., Bas, O./The Effect of the Kinanthropometric Profile on Leg Strength and Hand Grip Strength in Young Female Swimmers

addition, the variance inflation factor (VIF) coefficients were checked to determine whether significant multiple connections were present between the independent variables included in the estimation model. Coefficients for regression parameters obtained via estimation using the least squares model can lead to misinterpretation of the results if the
VIF is greater than 10. Independent variables with an insignificant contribution to the model using stepwise regression analysis were therefore removed from the model. In addition, relationships between characteristic were examined using Pearson's correlation coefficient. All statistical calculations were performed on SPSS version 22.0 software.

\section{RESULTS}

Table 1. Descriptive statistics for the characteristics investigated

\begin{tabular}{|c|c|c|c|c|c|c|}
\hline Parameters & $\mathrm{n}$ & Average & $\begin{array}{l}\text { Std. } \\
\text { Deviation }\end{array}$ & Min & Max & $\begin{array}{l}\text { Kolmogorov-Smirnov test } \\
P \text {-values }\end{array}$ \\
\hline Age & 100 & 10,81 & 1,84 & 8,00 & 15,00 & 0,046 \\
\hline Weight & 100 & 42,82 & 11,43 & 22,10 & 71,30 & 0,719 \\
\hline Height & 100 & 147,67 & 12,93 & 117,00 & 173,70 & 0,125 \\
\hline Sitting height & 100 & 79,36 & 7,07 & 63,80 & 92,30 & 0,443 \\
\hline Biacromial distance & 100 & 34,51 & 3,10 & 27,30 & 41,10 & 0,837 \\
\hline Biiliocrestal breadth & 100 & 26,73 & 3,05 & 19,00 & 35,60 & 0,870 \\
\hline Anteroposterior thorax & 100 & 17,54 & 2,06 & 13,80 & 24,00 & 0,551 \\
\hline Transversal thorax & 100 & 24,75 & 2,63 & 18,90 & 31,20 & 0,807 \\
\hline Head circumference & 100 & 52,72 & 3,99 & 25,00 & 57,00 & 0,001 \\
\hline Shoulder circumference & 100 & 85,37 & 7,91 & 68,00 & 107,00 & 0,794 \\
\hline Arm circumference & 100 & 22,62 & 2,73 & 16,20 & 30,30 & 0,888 \\
\hline Humerus size & 100 & 27,03 & 3,05 & 20,60 & 33,20 & 0,384 \\
\hline Forearm circumference & 100 & 20,73 & 1,95 & 16,50 & 26,10 & 0,334 \\
\hline Forearm length & 100 & 23,02 & 2,45 & 17,20 & 27,90 & 0,455 \\
\hline Wrist circumference & 100 & 14,13 & 1,04 & 11,40 & 16,70 & 0,648 \\
\hline Hand length & 100 & 16,26 & 1,81 & 11,90 & 26,30 & 0,362 \\
\hline Hand breadth & 100 & 7,07 & 0,56 & 6,00 & 8,20 & 0,038 \\
\hline Upper extremity length & 100 & 64,69 & 6,50 & 48,20 & 77,30 & 0,137 \\
\hline Lower extremity length & 100 & 77,55 & 10,45 & 7,30 & 93,20 & 0,353 \\
\hline Hip circumference & 100 & 78,69 & 8,78 & 61,50 & 102,00 & 0,450 \\
\hline Thigh circumference & 100 & 45,61 & 6,00 & 32,60 & 67,60 & 0,951 \\
\hline Femurlength & 100 & 35,23 & 3,52 & 26,70 & 42,10 & 0,756 \\
\hline Calf circumference & 100 & 30,18 & 3,35 & 22,90 & 39,00 & 0,870 \\
\hline Foot breadth & 100 & 8,75 & 0,71 & 7,30 & 10,20 & 0,719 \\
\hline Foot length & 100 & 22,72 & 1,71 & 17,80 & 26,70 & 0,983 \\
\hline Hand grip strength & 100 & 19,90 & 5,95 & 8,50 & 32,20 & 0,185 \\
\hline Leg strength & 100 & 47,28 & 15,30 & 21,00 & 88,50 & 0,711 \\
\hline
\end{tabular}

Examination of the study data using the Kolmogorov-Smirnov test revealed that the characteristics investigated were normally distributed( $p>0.05)$. Descriptive statistics for the characteristics of the participants in this study were therefore expressed as number, mean, standard deviation, minimum and maximum values, with $\mathrm{p}$ values for the Kolmogorov-Smirnov test results, and these are shown in Table 1. 
Degrees and directions of correlation between the variables in this research were determined using Pearson's correlation. Examination of correlation coefficients revealed significant positive correlations among hand grip strength and length strength and the various characteristics investigated (age, height, weight, etc.) Table 2.

Table 2. Correlation Coefficients and Significance Tests between Innovation Performance and Human Resource Strategies

\begin{tabular}{|c|c|c|}
\hline Features & Hand grip strength & Legstrength \\
\hline Age & $0,762^{* *}$ & $0,711^{\text {** }}$ \\
\hline Weight & $0,558^{* *}$ & $0,518^{* *}$ \\
\hline Height & $0,793^{* *}$ & $0,723^{* *}$ \\
\hline Sitting height & $0,767^{* *}$ & $0,730^{* *}$ \\
\hline Biacromial distance & $0,763^{* *}$ & $0,698^{* *}$ \\
\hline Biiliocrestal breadth & $0,683^{* *}$ & $0,647^{* *}$ \\
\hline Anteroposterior thorax & $0,669^{* *}$ & $0,646^{* *}$ \\
\hline Transversal thorax & $0,633^{* *}$ & $0,567^{* *}$ \\
\hline Head circumference & $0,339^{* *}$ & $0,295^{* *}$ \\
\hline Shoulder circumference & $0,725^{* *}$ & $0,680^{* *}$ \\
\hline Arm circumference & $0,635^{* *}$ & $0,569^{* *}$ \\
\hline Humerus size & $0,708^{* *}$ & $0,642^{* *}$ \\
\hline Forearm circumference & $0,663^{* *}$ & $0,642^{* *}$ \\
\hline Forearm length & $0,753^{* *}$ & $0,662^{* *}$ \\
\hline Wrist circumference & $0,526^{* *}$ & $0,505^{* *}$ \\
\hline Hand length & $0,705^{* *}$ & $0,621^{* *}$ \\
\hline Hand breadth & $0,679^{* *}$ & $0,596^{* *}$ \\
\hline Upper extremity length & $0,754^{* *}$ & $0,690^{* *}$ \\
\hline Lower extremity length & $0,657^{* *}$ & $0,611^{* *}$ \\
\hline Hip circumference & $0,668^{* *}$ & $0,600^{* *}$ \\
\hline Thigh circumference & $0,589^{* *}$ & $0,551^{* *}$ \\
\hline Femurlength & $0,697^{* *}$ & $0,659^{* *}$ \\
\hline Calf circumference & $0,683^{* *}$ & $0,647^{* *}$ \\
\hline Foot breadth & $0,558^{* *}$ & $0,518^{* *}$ \\
\hline Foot length & $0,741^{* *}$ & $0,684^{* *}$ \\
\hline
\end{tabular}

The effect of the characteristics examined (age, height, weight, etc.) on hand grip strength was determined using multiple regression analysis, the findings being shown in Table 3.

The correlation between hand grip strength and the characteristics examined in the research was estimated using stepwise regression analysis, and regression analysis results contributing significantly to the regression equality are shown in Table 4.

Age, hand length, foot length, biacromial distance and transversal thorax were found to make a statistically significant contribution to the model at stepwise multiple regression analysis applied to identify characteristics affecting hand grip strength (Table 4). 
Nefesoğlu, İ.C., Bas, O./The Effect of the Kinanthropometric Profile on Leg Strength and Hand Grip Strength in Young Female Swimmers

Table 3. Regression Analysis Results for Hand Grip Strength (for all characteristics)

\begin{tabular}{|c|c|c|c|c|c|}
\hline Variables & $b_{i}$ & $\mathrm{~S}_{\mathrm{bi}}$ & $t$ & P-values & VIF - values \\
\hline Fixed & $-48,099$ & 18,261 & $-2,634$ & 0,010 & \\
\hline Age & 1,052 &, 355 & 2,961 & 0,004 & 3,993 \\
\hline Weight & $-0,232$ & 0,215 & $-1,078$ & 0,285 & 56,263 \\
\hline Height & 0,057 & 0,156 & ,365 & 0,716 & 38,173 \\
\hline Sitting height & $-0,071$ & 0,181 &,- 392 & 0,696 & 15,201 \\
\hline Biacromial distance & 0,887 & 0,415 & 2,137 & 0,036 & 15,406 \\
\hline Biiliocrestal breadth & 0,217 & 0,277 & ,785 & 0,435 & 6,648 \\
\hline Anteroposterior thorax & 0,575 & 0,390 & 1,473 & 0,145 & 6,055 \\
\hline Transversal thorax & $-0,469$ & 0,404 & $-1,162$ & 0,249 & 10,541 \\
\hline Head circumference & 0,048 & 0,109 & ,436 & 0,664 & 1,777 \\
\hline Shoulder circumference & $-0,093$ & 0,156 &,- 597 & 0,552 & 14,131 \\
\hline Arm circumference & 0,444 & 0,339 & 1,311 & 0,194 & 7,980 \\
\hline Humerus size & $-0,112$ & 0,366 & $-0,304$ & 0,762 & 11,650 \\
\hline Forearm circumference & 0,131 & 0,631 & 0,207 & 0,836 & 14,105 \\
\hline Forearm length & 0,390 & 0,507 & 0,769 & 0,444 & 14,315 \\
\hline Wrist circumference & $-1,394$ &, 728 & $-1,915$ & 0,059 & 5,368 \\
\hline Hand length &, 724 & ,306 & 2,363 & 0,021 & 2,860 \\
\hline Hand breadth & 1,676 & 1,363 & 1,230 & 0,223 & 5,498 \\
\hline Upper extremity length &,- 285 & ,264 & $-1,079$ & 0,284 & 27,530 \\
\hline Lower extremity length & 0,088 & 0,060 & 1,465 & 0,147 & 3,652 \\
\hline Hip circumference & $-0,053$ & 0,152 & $-0,346$ & 0,731 & 16,650 \\
\hline Thigh circumference & $-0,078$ & 0,136 & $-0,575$ & 0,567 & 6,186 \\
\hline Femurlength & $-0,161$ & 0,218 & $-0,741$ & 0,461 & 5,503 \\
\hline Calf circumference & 0,507 & 0,378 & 1,341 & 0,184 & 14,958 \\
\hline Foot breadth & $-0,127$ & 0,882 & $-0,144$ & 0,886 & 3,665 \\
\hline Foot length & 0,989 & 0,512 & 1,932 & 0,057 & 7,182 \\
\hline
\end{tabular}


Nefesoğlu, İ.C., Bas, O./The Effect of the Kinanthropometric Profile on Leg Strength and Hand Grip Strength in Young Female Swimmers

Table 4. Stepwise Regression Analysis Results for Hand Grip Strength

\begin{tabular}{llllll}
\hline Variables & $\mathrm{b}_{\mathrm{i}}$ & $\mathrm{s}_{\mathrm{bi}}$ & $t$ & P-values & VIF - values \\
\hline Fixed & $-34,772$ & 4,565 & $-7,618$ & $<0,001$ & \\
\hline Age & 1,036 & 0,278 & 3,728 & $<0,001$ & 2,607 \\
\hline Hand length (HL) & 0,705 & 0,262 & 2,694 & 0,008 & 2,230 \\
\hline Foot length (FL) & 0,699 & 0,318 & 2,198 & 0,030 & 2,961 \\
\hline Biacromial distance (BD) & 0,881 & 0,301 & 2,931 & 0,004 & 8,635 \\
\hline Transversal thorax (TT) & $-0,577$ & 0,284 & $-2,031$ & 0,045 & 5,571 \\
\hline
\end{tabular}

Dependent variable: Hand grip strength;

$R^{2}: 0,733 ;$ Corrected $^{2}: 0,719 ; F=51,683(P=<0,001)$

$b_{i}$ : regression coefficients sbi: indicate coefficients' standard errors.

Table 5. Regression Analysis Results for Leg Strength (for all characteristics)

\begin{tabular}{lllll}
\hline Variables & $\mathrm{b}_{\mathrm{i}}$ & $\mathrm{s} \mathrm{sbi}$ & $t$ & P-values \\
\hline Fixed & $-91,359$ & 55,087 & $-1,658$ & 0,101 \\
\hline Age & 2,725 & 1,072 & 2,542 & 0,013 \\
\hline Weight & $-0,073$ & 0,648 & $-0,113$ & 0,911 \\
\hline Height & $-0,345$ & 0,472 & $-0,730$ & 0,468 \\
\hline Sitting height & 0,783 & 0,545 & 1,437 & 0,155 \\
\hline Biacromial distance & 1,824 & 1,252 & 1,457 & 0,149 \\
\hline Biiliocrestal breadth & $-0,669$ & 0,836 & $-0,800$ & 0,426 \\
\hline Anteroposterior thorax & 1,784 & 1,177 & 1,515 & 0,134 \\
\hline Transversal thorax & $-1,466$ & 1,219 & $-1,203$ & 0,233 \\
\hline Head circumference & $-0,130$ & 0,330 & $-0,395$ & 0,694 \\
\hline Shoulder circumference & 0,245 & 0,469 & 0,523 & 0,603 \\
\hline Arm circumference & $-0,720$ & 1,021 & $-0,705$ & 0,483 \\
\hline Humerus size & $-0,305$ & 1,105 & $-0,276$ & 0,783 \\
\hline Forearm circumference & 2,034 & 1,904 & 1,068 & 0,289 \\
\hline Forearm length & $-0,160$ & 1,528 & $-0,105$ & 0,917 \\
\hline Wrist circumference & $-1,324$ & 2,196 & $-0,603$ & 0,548 \\
\hline Hand length & 1,122 & 0,924 & 1,214 & 0,229 \\
\hline Hand breadth & $-0,547$ & 4,112 & $-0,133$ & 0,895 \\
\hline Upper extremity length & $-0,095$ & 0,798 & $-0,119$ & 0,906 \\
\hline Lower extremity length & $-0,035$ & 0,181 & $-0,192$ & 0,848 \\
\hline Hip circumference & $-0,726$ & 0,459 & $-1,582$ & 0,118 \\
\hline Thigh circumference & $-0,032$ & 0,410 & $-0,077$ & 0,939 \\
\hline & & & & \\
\hline & & & & \\
\hline
\end{tabular}


Nefesoğlu, İ.C., Bas, O./The Effect of the Kinanthropometric Profile on Leg Strength and Hand Grip Strength in Young Female Swimmers

\begin{tabular}{lllll}
\hline Femurlength & 0,539 & 0,657 & 0,820 & 0,415 \\
\hline Calf circumference & 1,068 & 1,141 & 0,936 & 0,352 \\
\hline Foot breadth & $-0,366$ & 2,660 & $-0,138$ & 0,891 \\
\hline Foot length & 2,496 & 1,544 & 1,616 & 0,110 \\
\hline
\end{tabular}

Hand grip strength increased in line with participants' age, hand length, foot length, and biacromial distance values, and decreased astransversal thorax values increased.

Multiple regression analysis was applied to determine the effect on leg strength of the characteristics examined in the research (age, height, weight, etc.), and the results are shown in Table 5.

Stepwise regression was employed to estimate the relationships between participants' leg strength and the characteristics investigated (age, height, weight, etc.), and regression analysis results contributing significantly to the regression equality are shown in Table 6.

Age, sitting height, and foot length were identified as making a statistically significant contribution to the model at stepwise multiple regression analysis performed to determine characteristics affecting participants' leg strengths (Table 6). Leg strength increased in line with participants' age, sitting height, and foot length.

Table 6. Regression Analysis Results for Leg Strength

\begin{tabular}{lrrrrr}
\hline Variables & $\mathrm{b}_{\mathrm{i}}$ & $\mathrm{S}_{\mathrm{bi}}$ & \multicolumn{1}{c}{$t$} & P-values & VIF values \\
\hline Fixed & $-79,667$ & 13,910 & $-5,727$ & $<0,001$ & \\
\hline Age & 0,544 & 0,282 & 1,930 & 0,057 & 4,165 \\
\hline Sittingheight $(\mathrm{SH})$ & 2,897 & 0,849 & 3,410 & 0,001 & 2,559 \\
\hline Footlength $(\mathrm{LH})$ & 2,308 & 0,952 & 2,424 & 0,017 & 2,790 \\
\hline
\end{tabular}

Dependent variable: Leg strength

$R^{2}$ : 0.608; Corrected $R^{2}: 0,596 ; F=49,720(P=<0,001)$

$b_{i}$ : regression coefficients sbi: indicate coefficients' standard errors.

\section{DISCUSSION AND CONCLUSION}

Anthropometric and somatotypic measurements have become highly important in determining ability in studies from the dawn of sports science to the present day. Which body profile will be best suited to which branch of sport has been discussed in studies of anthropometric measurements, together with the kind of role that this will play in talent selection (Ayan and Kavi, 2016).

The anthropometric characteristics of swimmers exhibiting high levels of performance affect the anatomical and physiological growth and development of athletes in early adolescence and adolescence, while genetic characteristics are also associated with factors impacting on sporting performance (Rowland, 2005).

Based on the findings of the present study examining the effects of the anthropometric measurements of 100 young female swimmers on hand grip and leg strength,their mean hand grip strength was $19.90 \pm 5.95 \mathrm{~kg}$. Measurements identified as significantly affecting hand grip strength were athletes' mean age at10.81 \pm 1.84 years, mean hand length at $16.26 \pm 1.81 \mathrm{~cm}$, mean foot length at $22.72 \pm 1.71 \mathrm{~cm}$, mean biacromial distance at 
$34.51 \pm 3.10 \mathrm{~cm}$, and mean transversal thorax at $24.75 \pm 2.63 \mathrm{~cm}$.

Hand grip strength increased in line with participants' age, hand length, and biacromial distance values, and these effects on hand grip strength were found to be statistically significant $\quad(\mathrm{p}<0.05)$. Another surprising finding from this study is that hand grip strength decreased as transversal thorax values increased.

One study investigated the physical characteristics of children aged 8-10 years, and since the research involved individuals of very similar ages, weight for age values were also similar. Reported mean weight and height for male students in the same age group were $30.67 \pm 6.90 \mathrm{~kg}$ and $133.01 \pm 5.99 \mathrm{~cm}$ (Ayan and Mülazimoğlu, 2009).

Anthropometric characteristics such as age, and hand, foot, ear, and leg length are more dependent on genetic than environmental factors. However, body circumference and diameter, body weight, and fat ratio are affected by environmental factors such as nutrition and exercise (Malina, 1984).

One study investigating physical suitability parameters in children aged 9-10 years reported that body weight increased in line with height in both sexes. The authors also found that hand grip strength in girls is positively affected as height increases (Haslofça, Haslofça and Kutlay, 2011). The findings of that study are completely contrary to our own results.

Yörükoğlu and Koz (2007) reported that the increase in mean height is a process that continues from birth to maturity. The age factor also occupies an important place in the development of sporting performance in children, and this is also known to affect height. Günay (2013) compared groups of elite swimmers aged 12-16 years and reported significant increases in height values in male and female swimmers aged 9-11 years who engaged in regular training. This was attributed to the increases in children's height values being a process beginning with birth and continuing to maturation.

Basic values have been set out in studies from different branches of sport. Mean reported height among basketball players, irrespective of gender, was $143.02 \pm 0.06 \mathrm{~cm}$ for players aged 8-15, $158.49 \pm 0.07 \mathrm{~cm}$ for those aged 58 , and $168.77 \pm 0.11 \mathrm{~cm}$ for youth team players aged 15-18 Mean height values among volleyball players was $142.73 \pm 0.09$ $\mathrm{cm}$ for players aged $8-15,156.90 \pm 0.09 \mathrm{~cm}$ in the 5-8 age group, and $169.75 \pm 0.08 \mathrm{~cm}$ for players aged 15-18. Mean heights among handball players were $137.71 \pm 0.06 \mathrm{~cm}$ for the 8-15 age group, $164.20 \pm 0.08 \mathrm{~cm}$ for the 5-8 age group, and $169.68 \pm 0.08 \mathrm{~cm}$ for players aged 15-18 (Pinar, 2005). Mean height among female swimmers in the present study was $147.67 \pm 12.93 \mathrm{~cm}$. In the light of the previous literature and our own research, height varies depending on age and the branch of sport concerned.

Özlü (2012) reported a mean age among swimmers of $23.29 \pm 2.65$ years, a mean height of $175.19 \pm 10.62 \mathrm{~cm}$, and a mean body weight of $69.84 \pm 12.38 \mathrm{~kg}$.

Various previous studies have examined and compared anthropometric characteristics on the basis of gender among swimmers aged 1213 years, an important time for talent selection. Research findings have shown no statistically significant difference between the anthropometric characteristics of height and weight values among boy and girl swimmers ( $>0.05$ ), although the mean values were higher among girls (Bostancı, Ateş, Yılmaz and Kabaday1, 2017).

In another study, 30 athletes were employed as subjects -18 footballers and 12 badminton players, and physical and physiological characteristics were compared between the branches. No statistically significant differences were determined between the footballers and badminton players in terms of age, height, body weight, or left hand grip strength ( $p>0.05)$. Footballers' mean right and left hand grip strength values were $17.11 \pm$ $4.40 \mathrm{~kg}$ and $15.62 \pm 3.41 \mathrm{~kg}$, respectively, compared to $15.21 \pm 1.70 \mathrm{~kg}$ and $14.68 \pm 2.86$ $\mathrm{kg}$ for the basketball players. The difference between the participants' left hand grip strengths was not statistically significant, but mean right hand strength was higher among footballers compared to badminton players (Kürkçü, 2009). 
In their study of children taking part in sporting activities, Ziyagil, Tamer, Zorba, Uzuncan ve Uzuncan (1996) reported a mean hand grip strength of $15.20 \pm 4.07 \mathrm{~kg}$ in the under-10 age group, $15.88 \pm 1.75 \mathrm{~kg}$ among children aged 11 , and $17.00 \pm 3.02 \mathrm{~kg}$ among children aged 12. Children taking part in sports exhibited greater hand grip strength than non-sporting children. Mean hand grip strength in the present study was $19.90 \pm 5.95$ $\mathrm{kg}$. We think that the greater hand strength among swimmers may derive from their constant use of their hands due to the nature of their sport.

Studies of hand grip strength have reported right-hand values of $47.5 \pm 8.05 \mathrm{~kg}$ in volleyball, $47.05 \pm 9.04 \mathrm{~kg}$ in handball, $48.98 \pm 6.48 \mathrm{~kg}$ in wrestling, and $38.31 \pm 5.38$ $\mathrm{kg}$ in football. Reported left-hand grip strengthsare $45.97 \pm 9.93 \mathrm{~kg}$ in volleyball, $44.31 \pm 7.97 \mathrm{~kg}$ in handball, $49.57 \pm 5.31 \mathrm{in}$ wrestling, and $39.61 \pm 3.66$ in football. Comparison of right and left-hand grip strengths revealed significant difference among the branches $(\mathrm{p}<0.05) \quad$ (Çolak and Kolukısa, 2017).

One study reported a mean right-hand (dominant) grip strength among handball players of $57.69 \pm 8.07 \mathrm{~kg}$, and $53.24 \pm 6.65$ for left-hand grip strength, the difference being significantly in favor of the dominant hand $(p<0.01)$. Control group hand grip strengths were $46.02 \pm 8.13 \mathrm{~kg}$ for the right (dominant) hand and $43.32 \pm 6.91 \mathrm{~kg}$ for the left hand, the difference also being significantly in favor of the dominant hand $(\mathrm{p}<0.01)$. Comparison of handball and control group hand grip strength values revealed a statistically significant difference in favor of handball players on both right and left $(\mathrm{p}<0.01)$. These differences were attributed to physical characteristics such as handball players' height and weight, and to their physical activities (Yıldırım, Baş, Kabadayı, Taşmektepligil, Ocak and Karagöz, 2010).

Factors identified as making a statistically significant contribution to the stepwise multiple regression analysis model for determining characteristics affecting participants' leg strength were age, sitting height, and foot length. Leg strength increased in line with participants' age, siting height, and foot length.

In their research involving elite female handball players, Sevim, Sevim, Günay and Erol, (1996) reported a mean pre-training leg strength of $119.9 \pm 2.7 \mathrm{~kg}$, compared to $127.7 \pm 22.8 \mathrm{~kg}$ after training.

Strength increases with muscle mass. Studies have reported a significant increase in participants' leg strength and a significant decrease in body fat percentages. The low level of decrease in body weight despite taking part in an eight-week exercise program may therefore be associated with an increase in muscle mass (Kurt, Hazar, İbiş, Albay and Kurt, 2010).

One study involving leg strength involved total 14 (age: $18.78 \pm 0.41$ years) young, female members of the Turkish national basketball team playing for different clubs. The participants' height, and body weight, circumference, and diameter were measured. An isometric leg-back strength dynamometer was employed to determine back and grip strength. The results showed that the basketball players possessed moderate back strength $(83.35 \pm 11.68 \mathrm{~kg})$, leg strength $(87.75 \pm 8.34 \mathrm{~kg})$, right hand grip strength $(34.73 \pm 3.28 \mathrm{~kg})$, and left hand grip strength $(32.82 \pm 3.57 \mathrm{~kg})$. Pearson's product moment correlation coefficient method was used to evaluate relationships between back, leg, and grip strength values. Positive correlation was also determined between right hand grip and let hand grip strength values $(\mathrm{r}=.859, \mathrm{p}<001)$ (Akyüz, Özkan, Taş, Sevim, Akyüz and Uslu, 2014).

In a study of first and second league tennis players, Gelen, Saygın, Karahan and Karacabey (2006) reported mean leg strength values of $185.1 \pm 9.60 \mathrm{~kg}$ for first league players and $173.9 \pm 110.14 \mathrm{~kg}$ for second league players.

Another study involving leg strength among athletes reported lower leg strength values among individuals from shooting sportsat $64 ; 00 \mathrm{~kg}$, compared to other branches of sport (athletics $100.12 \mathrm{~kg}$, fencing $102.02 \mathrm{~kg}$, and swimming $86.90 \mathrm{~kg}$ ) (Pulur, Ceylan and Karaçam, 2017). 
Similar studies from various different branches have reported comparable to findings to those of the present study. Mean leg strength among the female swimmers in the present study was $47.28 \pm 15.30 \mathrm{~kg}$. Measurements significantly affecting leg strength were the athlete's age, sitting height, and foot length. Analysis of the anthropometric characteristics of the athletes in this study showed that hand grip strength increased in line with age, hand length, foot

\section{Acknowledgments}

I would like to thank athletes and coaches who participated in the research.

\section{Author Contributions}

Study concept/Design: Orhan Baş; Data Collection: İbrahim Can Nefesoğlu, Orhan Baş; Data Analysis and Interpretation: Orhan Baş; Post draft: İbrahim Can Nefesoğlu, Orhan Baş; Critical review of the content: Orhan Baş; Final approval and responsibility: İbrahim Can Nefesoğlu, Orhan Baş; Supervision: Orhan Baş

\section{Conflict of interest}

There are no conflicts of interest.

\section{REFERENCES}

Atasoy, H. (2018). An investigation of the effects of swimming training on freestyle degrees and some anthropometric and motoric characteristics of performance swimmers aged 8-10. İstanbul Gelişim University Master's thesis.

Akdoğan, I., Özdemir, B.,Hasusta, A.,Akyer, P., Akdoğan, D. and Akdağ, B. (2005). Anthropometric body circumference and upper extremity length measurements in first grade (7 years of age) students in Denizli city center. SDÜ Medical Faculty Journal, 12(4), 1418.

Akyüz, M., Özkan, A., Taş, M., Sevim, O., Akyüz, Ö. and Uslu, S. (2014). Determining and Associating the length, and biacromial distance values. Hand grip strength also decreased as transversal thoracic values increased. The athlete's age, sitting height, and foot length were found to exhibit a significant effect on leg strength. The athletes taking part in this studies, and their coaches, were informed about the study findings. We think that the provision of comprehensive information will be a useful guide to the establishment of individualized training programs.

\section{Funding Disclosure}

This study was supported by the Ordu University Scientific Research Coordination Office under project number BY-1727.

\section{Ethical Approval}

The study began after receiving permission from Ordu University Clinical Research Ethics Committee dated 10.08.2017 and numbered 91. Declaration of Helsinki was followed in this study design and report.

\section{Peer Review Process}

Extremely peer-reviewed
Strength Profiles of Girl Athletes in the Junior Basketball National Team. International Journal of Science Culture and Sport, 1(3), 39-48.

Alp, M., Kılınç, F. and Suna, G. (2015). An investigation of the effects of training applied to handball players in the preparatory season on various anthropometric and biomotor characteristics. sstb International Refereed Academic Journal of Sports, Health \&Medical Sciences, 17.

Arabac1, R. (2008). The talent selection in sports and guidance project for the Olympics, an examination of the second stage results (Bursa sample). 
Ayan, V., Kavi, N. (2016). An Examination of Somatotype Structures and Horizontal Jumping Characteristics of Girls Aged 8-14, International Journal Of Science Culture and Sport, 4/1.

Ayan, V. \& Mülazimoğlu, O. (2009). An examination of the physical characteristics and some performance profiles of 8-10 yearold boys in sports talent selection and orientation to sports (an Ankara sample). FÜ Journal of Health Sciences Medicine, 23(3), 113-118.

Baş, O., Paktaş, Y., Özen, OA., Songur, A., Üçok, K., Mollaoğlu, H., Toktaş, M. (2006). Some Anthropometric Measurements of the Upper Extremities of Male Volleyball Players. The Medical Journal of Kocatepe. 7: 45-48.

Bompa, TO. (1985). Talent identification Sports Periodical on Research and Technology in Sport, 1-11.

Bostanc1, Ö., Ateş A., Yılmaz, A.K., Kabadayı M. (2017) A comparison of the anthropometric characteristics of 12-13 year-old swimmers by gender. İnönü University Journal of Physical Education and Sports Sciences, 4(3), 12-21.

Canlı, U. (2016). The relationship between secondary school students' anthropometric, biomotor and physiological characteristics and academic success, Doctoral thesis. Department of Physical Training and Sports Education, Gazi University, Ankara.

Çıkmaz, S.,Taşkınalp, O.,Uluçam, E., Yılmaz, A. \& Çakıroğlu, M. (2005). Anthropometric measurements and body proportions in football players. Balkan Medical Journal, (1), 32-36.

Çolak, H. \&Kolukısa, Ş (2017). A Comparison of Various Motoric Properties of Athletes in Different Branches. Journal of Current Researches on Social Sciences, 7(2), 307-316.

Dündar, U. (2015). Training Theory, $9^{\text {th }}$ edition. Ankara, Nobel Akademic Publishing: 130, 246, 339, 345.

Ergün, N., Baltacı G. (1997). Physiotherapy and Rehabilitation Principles in
Sporting Injuries, $1^{\text {st }}$ edition. Ankara Ofset Fotomat, 28.

Fry, R.W. Morton, A.R. (1991). Physiological and Kinanthropometric Attributes of Elite Flatwater Kayakists. Medicine and Science in Sports and Exercise. 23: 1297-1301.

Gelen, E., Saygın, Ö., Karahan, M., Karacabey, K. (2006). A Comparison of Physical Fitness Features of Tennis Players in Leagues I and II. Firat University Journal of Health Sciences, 20(2), 119-127. Elazı ğ.

Günay, E. (2007). "The Effect of Regular Swimming Practice on Children's Physical and Physiological Parameters," Master's thesis, Gazi University Graduate School of Health Sciences, Ankara.

Günay, E (2013). The Effect of Training at Different Heights on the Swimming Performance of Elite Swimmer, Doctoral thesis. Erciyes University Health Sciences Institute.

Haslofça, E.,Haslofça, F. \& Kutlay, E. (2011). Relationships between physical fitness parameters in 9-10 year-old childre. Sport Refereeing Journal, 46(2), 067-076.

İçten, N., Süllü, Y., Tuncer, I. (1995). Height and lower extremity measurements of girls in the 17-20 age group in the Black Sea region. Ondokuz Mayıs University Medical Journal. 12(3):207-213.

İkiz, İ., Yılmaz, O., Akça, C., Çankaya, C. (1995). 633. Kirkpinar. Some Anthropometric Measurements of the Extremities of Wrestlers Participating in Oil Wrestling. Morphology Journal. 3(2): 16-9.

Kılınç, F., Cesur, G., Atay, E., Ersöz, G., \& Kilıç, (2010). T. An investigation of physical, physiological and strength factors affecting the technical shooting performance of 10-14 age group elite female archers. SDU Medical Faculty Journal, 17(3), 18-24.

Kızılakşam, E. (2006). "A Comparison of Eurofit Test Batteries Application Results of Students Actively Engaged in Sports and Not Engaged in Sports (Entering Physical Education Classes) in Edirne City Center Primary 
Schools" (Master's thesis)., Edirne: Trakya University Health Sciences Institute.

Kurt, S., Hazar, S., İbiş, S., Albay, B. \& Kurt, Y. (2010). An evaluation of the effects of eight-week stepaerobic exercise on various physical fitness parameters in middle-aged sedentary women. International Journal of Human Sciences, 7(1), 665-674.

Korkmaz, HN., Arabacı, R., Çankaya, C., Şahin, S. (2008). An Investigation of Body Mass Index and Waist-Hip Ratios in 8-14 Year-Old Children Participating in International Sports Festivals (Bursa sample). 10th International Sport Sciences Congress, October 23-25, S.436 Bolu.

Kürkçü R. (2009). The Training Programme Which is used 12 week for wrestlers effects on some physical and physiologic properties. Sport Sciences, 4(4), 313-321.

Lale, B.,Müniroğlu, S., Çoruh, EE., Sunay, H. (2003). An Investigation of Somatotype Features of theTurkish National Men's Volleyball Team. Spormetre, Journal of Physical Education and Sports Sciences, 1: 53-56.

Le, BR.,Labelle, H., Forest, F., Poitras, B. (1998). Morphologic Discrimination Among Healthy Subjects and Nonprogressive Adolescent Idiopathic Scoliosis Spine, 23.1109-1116.

Malas, M., Doğan, Ş., Evcil, EH.,Desdicioğlu, K.,Tağıl, S., M. Sulak, O. \& Çetin, E. (2005). Growth rates between the upper and lower extremities in the fetal period. SDÜ Medical Faculty Journal, 12(2), 1-8.

Malina, RM. (1984). Human Growth Maturation and Regular Physical Activity Advances in Pediatric Sport Sciences. Champaign, IL, Human KineticsPub, pp 59-83.

McArdle, WD. (1971). Exercise Physiology Energy, Nutrition and Human Performance. Philadelphia.pp:30.

Otman, S., Demirel, H., Sade, A. (2014). Basic Assessment Principles in Therapeutic Movements. $2^{\text {nd }}$ edition, Ankara: Pelikan Publishing.
Özer, K. (2009). Kinanthropometry. Morphological Planning in Sport. $2^{\text {nd }}$ edition Ankara; Nobel Akademic Publishing .

Özkan, A. \&Sarol, H. (2008). A comparison of some physical fitness and somatotype characteristics of alpine and rock climber. Gazi Journal of Physical Education and Sport Sciences, X III(3):3-10.

Özlü, M. (2012). The effect of anthropometric and kinematic parameters on $50 \mathrm{~m}$ freestyle swimming performance, Mater's thesis, Health Sciences Institute, Konya.

Pate, RR.,Freedson, PS., Sallis, JF. (2002). Compliance with Physical Activity Guidelines: Prevalence in a Population of Children and Youth, AEP; 12: 303-308.

Pavlicevic, S. (2005). Somatic and physical traits affecting sprint swimming performance in young swimmers. Int J Sports Med, 26: 139-44.

Pınar, D. (2005). A Comparison of Anthropometric Measurements and Hand Grip Strength in Different Sports Branches, Master's thesis, Karaelmas University Health Sciences Institute, Zonguldak.

Pulur, A., Ceylan, MA., Karaçam, A. (2017). An investigation of some physical and physiological characteristics of individual athletes participating in intercollegiate championships.

Rowland,Tw. (2005). Children's Exercise Physiology, Human Kinetics, ed. Bradford Road, Stanningley Leeds, United Kingdom.

Saygın, Ö., Polat, Y., Karacabey, K. (2005). The Effects of Movement Training on Physical Fitness Traits in Children, F.Ü. Health Sciences Journal: 19(3), 205-212.

Sevim, M., Sevim, Y., Günay, M., Erol, E. (1996). An Investigation of the Effects of Combined Strength Training on Performance Improvement in Elite Female Handball Players aged 18-25. College of Physical Education and Sports Sciences Journal, Vol. 1, No. 3, p. 1-6, Ankara.

Thomas, EM.,Sahlberg, M.,Svantesson,U. (2008). The effect of resistance training on hand grip strength in 
young adults. Isokinetics and Exercise Science, Volume 16, Number 2 / 125-131.

Tuncer, I. (2004). Evaluation of Growth and Development in Primary School Students in Konya City Center with Various Anthropometric Measurement. İnönü University Medical Faculty Journal 11(4) 233236.

Turnagöl, H., Demirel, H., Arıtan, S. (1992). The Somatotype Characteristics of National Athletes, Second National Sports Sciences Congress Reports, Hacettepe University, Sports Sciences Vocational School Publication 3, pp.411, Ankara.

Yıldırım, İ., Baş, O., Kabadayı, M., Taşmektepligil, Y., Ocak, Y. \& Karagöz, Ş. (2010). An investigation of the relationship between hand grip strength and upper extremity physical characteristics of male Super League handball players. Mustafa Kemal University Journal of Physical Education and Sports Sciences Vol. 1, No. 1.

Yörükoğlu, U., Koz, M. (2007). The effects of sports school studies and basketball training on the physical, physiological and anthropometric properties of 10-13 age group boys. Spormetre Physical Education and Sports Sciences Journal, 5 (2), 79 83.

Yusufreisoğlu. Ö. (2009). The effect of regular training on anthropometric development in athletes aged 1214, Master's thesis, Sakarya University Social Sciences Institute.

Ziyagil, MA., Tamer, K., Zorba, E., Uzuncan, S., Uzuncan, H. (1996). An Evaluation of the Physical Fitness and Anthropometric Properties of Male Primary School Students Aged between 10 and 12 Years Old By Age Groups and Exercising Habits Using the Eurofit Test Battery, Gazi Journal of Physical Education and Sports Sciences, Bo. 4, 1996, pp 25-27.

Zorba, E. (1999). Sport and physical fitness for all. Neyir Publishing. Ankara.

Zorba, E.,Ziyagil, M A. (1995). Body Composition and Measurement Methods, Trabzon, Turkey. 